\title{
Leveraging on Religious and Ethical Aspects in Marketing Takaful Products- Malaysian Experience
}

\author{
Assist. Prof. Dr. Akhtarzaite Abdul Aziz \\ Department of Figh and Usul al-Figh, Kulliyyah of Islamic \\ Revealed Knowledge and Human sciences, International Islamic University Malaysia
}

\begin{abstract}
Takaful serves as an alternative for the Muslims to fulfill their insurance needs in a Shariah compliant manner. Participating in a takaful scheme, while aimed mainly at gaining protection against the risks, could also be perceived as a scheme of mutual help. The religious and ethical aspects of takaful can be an attractive value proposition to the people especially Muslims, as in Islam helping those in need with sincere intention for the sake of Allah is an act of piety rewarded by Him. Apart from the inherent spiritual distinctive feature of takaful, takaful products might also provide for other religious contentment. Some takaful products cover debt settlement for the deceased, payment for outstanding zakat, execution of charitable donation or waqaf and even providing for the performance of hajj, which are religiously of tremendous values for the deceased. All these features could be attractive marketing points for takaful especially among the Muslims. This study focuses on the religious and spiritual dimensions of takaful products and explores on the experience of a group of takaful agents of a selected takaful operator in marketing their products by leveraging on these aspects.
\end{abstract}

Keywords: Mutual Help, Religious, Ethical, Takaful marketing, Takaful Agent

\section{Introduction}

Takaful as an Islamic alternative to the modern conventional insurance is defined as a scheme based on mutual assistance, brotherhood and solidarity in accordance with the provisions of Shariah principles providing for mutual financial aid and assistance to the participants in case of occurrence of defined common risks. It is based on the mutual agreement among the participants to contribute to a common fund for the purpose of financial assistance to any member affected by the stipulated risk. Naturally, the very spirit and philosophy of takaful is closely related to Islamic teachings of helping each other in the times of need.

Insurance is one of the contemporary and recent developments in financial and economic activities even in the west. Therefore, the classical Muslim jurists did not specifically discuss it. However, the philosophy behind the insurance industry is not totally absent from the basic Islamic teachings. Generally, insurance policy is a contract of mutual financing in which one party is expected to be protected materially against an unexpected loss by the other party, in consideration of the payment of a particular amount of premium (Billah, 2003). Insurance is therefore a contract of exchange between two parties whereby the insured buys protection from the insurer at a price (premium) against a prescribed risk.

Contemporary Muslim jurists have discussed the above model of insurance in a series of discussions held since 1976. Most of them are of the opinion that conventional insurance is not allowed in Islam mainly because of the elements of riba and gharar. Below are some conferences held to discuss this issue and the resolutions they reached.

1) The First Conference on Islamic Economy, Mecca, 1976: Conventional insurance as practiced today does not comply with the spirit of Shariah and does not fulfil the requirements which might render it permissible.

2)10 th $^{\text {th }}$ Conference of Prominent Muslim Scholars, Saudi Arabia, 1977: Confirmed by consensus of opinion that conventional insurance in all its types is not permissible, whether it is life insurance or general insurance (on property).

3) The Islamic Fiqh Academy (OIC), Jeddah, 1985: Confirmed that conventional insurance is prohibited due to the uncertainties (gharar). The committee suggested as an alternative an insurance system based on cooperation and hibah (Mahmood, 1991). 
This gave birth to the present day takaful which provide for an alternative for conventional insurance. Takaful was defined under Section 2 of the Malaysian Takaful Act 1984 as: "A scheme based on brotherhood, solidarity and mutual assistance which provides for mutual financial aids and assistance to the participants in case of need, whereby the participants mutually agree to contribute for that purpose." The newly introduced Islamic Financial Services Act 2012 which takes effect from May 2013 similarly defined Takaful under Section 2 as "an arrangement based on mutual assistance under which takaful participants agree to contribute to a common fund providing for mutual financial benefits payable to the takaful participants or their beneficiaries on the occurrence of pre-agreed events."

Unlike in the case of conventional insurance, takaful or mutual insurance policy is not a contract of exchange. Rather, it is a contract of mutual hibah or gratuity, whereby all participants agreed to contribute to a common fund (INCEIF, 2012). In Islamic law, contracts can be divided into two types; the first type is contract of exchange (uqud muawadah) or bilateral contract, whereby there is mutual exchange of consideration from both parties.

The second type of contract is contract of gratuity or unilateral contract whereby the consideration comes from one party only (INCEIF, 2012). The elements of riba and gharar are prohibited in exchange contracts (uqud muawadah) and not operative in a contract of gratuity or hibah. Under takaful, the policyholders are both the insurer and the insured as they collectively and mutually guarantee each other against the stipulated risks. Hence, although there is still some uncertainty in takaful as to when the risk against which a participant is making contribution will materialize, it is considered as tolerable in a contract of gratuity, and does not render the contract null and void.

It follows from the above that takaful is different from insurance in term of the relationship between the parties. Under insurance contract, the insured buys the policy from the insurance company for a price or premium. On the other hands, under takaful policy, the relationship between the parties can be generally described as follows:

a) The relationship among the policyholders: All the policyholders are bound by the contract of partnership and hibah. They jointly own the funds in accordance with their contributions and undertake to mutually protect each other on the basis of hibah. An issue might appear here as the participant is expecting coverage from the fund to which he is making contribution, hence giving raise to the question whether it is truly a unilateral contract or actually bilateral in nature. As the validity of takaful contract depends on the fact that it is not an exchange contract, it is crucial to refute the argument.

It has been argued that takaful arrangement still qualify as unilateral contract despite the claimable contribution based on the principle of iltizam bi al tabarru (self-imposed donation) as it is made from one side and there is no inter-relation of one iltizam to the other. (ISRA, 2011)

b)The Takăful operator and the policyholders: The relationship can be viewed from two sides. Firstly, in its role as manager of the hibah funds and insurance claims, the company acts as an agent on behalf of the participants. Second, in its role as manager of the investment of the total funds accumulated, the takaful operator may play the role of mudarib or entrepreneur in a mudarabah contract or an agent with a fee.

The present study is divided into 3 parts, the first part will look into the religious aspects of takaful, with special reference to some takaful products in Malaysia. The second part will focus on the ethical aspect inherently underpinned takaful services. Finally, the third part will provide for an analysis of a survey conducted in one of selected takaful operator in Malaysia. The respondents are the marketing agents of the takaful operator to examine to what extend they understand the religious and ethical aspects of takaful and leverage on those aspect in marketing takaful products. The importance of result of the survey is twofold; firstly it can be used to improve their marketing strategy and secondly to enhance public understanding on the inherent religious and ethical aspects of takaful.

\section{Analysis on the religious aspects of takaful}

The concept of takaful and its underlying philosophy inherently very much close to Islamic teaching. Indeed, this has been reflected in the definition of takaful itself whereby it was defined as a scheme or an arrangement based on brotherhood, solidarity and mutual assistance which provides for mutual financial aids and assistance to the participants in case of need (Billah, 2003). The concept used in takaful products is tabarru'1 or donation whereby all the participants donated to a fund for mutual use in times of need as prescribed in the policy. In other words, by agreeing to the tabarru' part of their contributions, the participants agreed among themselves to cooperate and financially responsible to help one another.

\footnotetext{
${ }^{1}$ The word tabarru' here is used interchangeably with the word hibah, referring to the voluntary contribution by the participants.
} 
The philosophy of takaful based on tabarru' principle if properly understood and implemented could be a tremendous value add for takaful products. The participant while seeking for coverage against their potential risk might also at the same time appreciate the fact that they are actually providing the same for others by helping them when in need. Providing help while in need indeed a noble act and cherished by people of different faith, which could be seen in cases of earthquake, hurricane or tsunami whereby people from different parts of the world would respond and help financially the affected countries. While in these cases the donation took place after the tragedy, under the takaful concept, it is collected in orderly fashion within a specified group prior to the calamity. Furthermore the good deeds of helping others would be especially meaningful to Muslims who believe that these kind of acts would entail the pleasure of Allah and considered as act of piety (Ahmad Nordin, 2007). In many places in the Quran as well as Hadith of the prophet, the spirit of helping one another has been enjoined upon the Muslims. In Surah al Maidah Allah says: "Help one another in furthering virtue and God consciousness (taqwa) and do not help one another in furthering evil and enmity." 1 In a hadith narrated by Ibnu Majah the Prophet said: "Verily a believer is one who can give security and protection to the life and property of mankind. In another hadith narrated by Imam Ahmad ibn Hanbal and Imam Abu Daud, the Prophet reportedly said: "Allah will always help his slaves (mankind) so long as they are helping each other."

Apart from the inherent concept of tabarru' and helping each other imbued in all takaful products, specific products also has been innovated to achieve the religious contentment from worldly act of participating in takaful for risk coverage purposes. While conventional life insurance embarks on the slogan "life insurance is for the living" "(Ahmad Nordin, 2007) takaful might leverage further on the fact that "takaful is for the living and the deceased as well." Some family takaful operators had incorporated in their products certain features so that a Muslim can plan for the utilization of the takaful proceeds in case of his death for some religious purposes. For a Muslim, the life after death is a continuation of this worldly life and their fate in the eternal life will be determined by his fulfillment of his duties in this temporary world. Some takaful products provide opportunity for the Muslim to plan to fulfill some of these duties and recommended acts in case they are not able to perform them immediately.

For example, takaful may provide debt settlement coverage in the case of the debtor untimely death. Paying debt is a religious duty of the Muslim which has been strongly emphasis by Islam. In one occasion, in a hadith narrated by Imam Bukhari, the prophet refused to pray upon the body of a dead companion who left certain unsettled debt until another companion by the name of Abu Qutadah voluntarily offer to pay on his behalf. Thus, by having this takaful policy, a Muslim can be assured that his debt will be settled in the event of his death.

Another example is takaful product which provide for the payment of outstanding zakat obligation of the participant and substitution of Hajj performance (badal hajj) two of the five pillars of Islam which involve monetary implications. Some takaful products provide for extra coverage for death or total permanent disability (TPD) occurred during hajj or umrah performance. ${ }^{2}$

Apart from performance of religious duties, takaful product also can provide for philanthropy acts which are highly recommended in Islam like charitable waqaf or even to cover the education cost of orphans or less fortunate children. For waqf takaful product, the takaful benefit will be partly used to participate in buying waqaf property like mosques, hospitals or schools. This could be a strong motivation for a Muslim to participate in this type of takaful knowing that some allocation has been specified for continuous good deeds (amal jariah) after his death which might not be able to do immediately.

From the above 2 conclusions are indispensable. Firstly, takaful in general is imbued with noble underlying Islamic principle of helping each other. Secondly, takaful products may be supplemented with additional values innovatively by providing for the fulfillment of specific duties of the Muslim as well as other highly recommended acts for the betterment of the whole ummah.

\section{Analysis on the ethical aspects of takaful}

This part will examine the ethical aspects of takaful in relation to three underlying concepts which originated from the conventional insurance but equally applied in takaful namely the concept of Uberrimae Fidei or utmost good faith, underwriting policy and insurable interest.

\footnotetext{
${ }^{1}$ Al Maidah 5:2

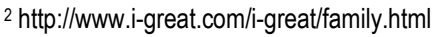




\section{1)Takäful and the concept of Uberrimae Fidei or utmost good faith}

The concept of uberrimae fidei or agreement of utmost good faith in insurance as explained by (Billah,2003) means that the parties to the policy or takaful plan must disclose the truth of the facts or the matters affecting the policy. Under the law, it is assumed that insurance contracts are entered into by all parties in good faith, meaning that they have disclosed all relevant facts and intend to carry out their obligations. Where lack of good faith can be proved, such as fraudulent application to obtain insurance, the contract may be nullified (Rubin, 2000). Under section 28 of the 1984 Takaful Act, it is the participants' duty to disclose in the proposal form fully and faithfully all the facts which they know or ought to know, otherwise the Takaful Certificate issued may be void (BIMB Institute of Research and Training (BIRT) 1996). As indemnity provided in takaful contract is based on the mutual responsibility of all participants, it is inherently a duty of each of them to disclose all material facts affecting the contract in order to achieve the objectives of transparency and justice. Failure to disclose might render the possibility of benefiting from the tabarru funds fraudulently at the expense of other participants.

\section{2)Takaful underwriting}

Underwriting is the process by which takaful operators consider and decide whether to accept participation of cover made by a "proposer" and the terms to be imposed. It is the process of examining, accepting or rejecting insurance risk and classifying those selected in order to charge the proper premium for each. Generally, the purpose of underwriting is to distribute the risk among a pool of insureds in a manner that is equitable for the insureds and profitable for the insurer (Rubin, 2000). The concept of underwriting is no less important in takaful, due to the solidarity and mutual assistance spirit inherent in takaful itself. Thus, the purpose of underwriting for family takaful for example is to maintain equity among the participants. In this case, each participant contributes to a common fund (tabarru fund) from which takaful benefits will be paid to any participant suffering from the risks defined. Therefore, each participant should contribute according to the expected loss probabilities that he might transfer to the fund. The takaful company should estimate the expected loss exposure presented to it by the participant and charge a rate or percentage to be attributed to the tabarru fund which is commensurate with that exposure (Ahmad, 1991).

Though underwriting policy and procedures originates from conventional insurance practice to ensure the insurance company's adequacy to compensate for the loss occurred, it is even more important in takaful ethically as the participants of takaful are both insurer and insured. Takâful, being a mutual insurance and mutual help in protection against loss, requires a reliable step in determining the fund's adequacy and capability in providing protection against loss for all members. This in return is an effective means towards ensuring transparency and justice, as the underwriting process provides transparency in determining the tabarru portion and ensures that any participant will not take from the fund more than what he deserves at the expense of other participants, unethically.

\section{3)Takäful and the Insurable Interest}

Insurable interest means the financial interest a person has in the subject matter of the cover. For its validity, insurance requires that the insured shall be so related to the subject matter of the insurance that he will benefit from its survival or will suffer from loss or damage to it or may incur liability in respect of it. The participant must stand in a relationship with the subject matter of the takaful whereby he benefits from its safety and well-being or freedom from liability and would be prejudiced by its damage or the existence of liability. A policy without an insurable interest is like a gambling contract that is clearly prohibited in Islam, by which a participant hopes for a chance to gain instead of providing a mutual cooperation for security against a risk (Billah, 2003).

Under the 1984 Takaful Act, there was no expressed condition for insurable interest for a takaful plan. In the case of life insurance, whereby the insurable interest is the life itself, it was argued that the question of requirement for insurable interest might not arise, as the participant in this case seeks to protect his and his family's interest. In takaful, the insured are themselves the insurers, and thus the element of gambling or the intentional self-inflicted harm will not be operative in a takaful for lack of insurable interest (Mahmood, 1991). Above all, the insurance benefit in a family takaful policy shall be distributed on the basis of the Islamic law of inheritance, as it is considered as part of the participant's legacy. The nominees in the policy are considered as mere trustees to administer the distribution of the takaful benefit after the participant's death.

However, the debate on the applicability of insurable interest has been settled in the newly introduced Islamic Financial Services Act 2012 whereby Schedule 8 of the Act statutorily requires permissible takaful interest. It provides: "a takaful participant entering into a contract of family takaful shall have a permissible takaful interest in the person covered at the 
time such contract of takaful is entered into and at the time the takaful benefits are payable. ${ }^{1}$ The following subsection stipulated the effect of the absent of permissible takaful interest on the validity of a takaful contract: "Where a takaful participant entering into a contract of family takaful does not have a permissible takaful interest in the person covered at the time such contract is entered into, the contract shall be void."2

Schedule 8 of the Act also specifically listed the persons having permissible takaful interest with the participant: "a person shall be deemed to have a permissible takaful interest in the person covered if that other person is:

(a) his spouse or child;

(b) his ward under the age of majority at the time the person entered into the contract of takaful;

(c) his employee; or

(d) a person on whom he is wholly or partly, dependent for maintenance or education at the time he entered into the contract of takaful."3

It could be concluded therefore that apart from religious aspects, the arrangement of takaful scheme also must be supplemented with some ethical and best practices to ensure that the noble objectives behind takaful itself could be achieved.

\section{Analysis of survey}

The survey was conducted in March 2013 distributed among 37 of takaful agents servicing a takaful operator namely Great Eastern Takaful. This takaful operator is actually a subsidiary of a group which also having a conventional life insurance company. Some of the respondents provide services to both insurance and takaful simultaneously. 11 out of the 37 respondents $(29.7 \%)$ had the experience as takaful and/or insurance agent for more than 10 years.

The result of the survey shall be analysed in accordance with 2 main objectives:

1)To what extent the agents understand the ethical and religious features of takaful

2) To what extent they leverage on the ethical and religious aspects in marketing takaful products.

As for the first part, the objective is to measure understanding on takaful concept among takaful agents. This is important before measuring their reliance on ethical and religious aspects of takaful in marketing. For this part 4 questions were asked pertaining to the nature of takaful. The result of the survey for the first question shows $43 \%$ agreed or strongly agreed that the concept of takaful is very similar to conventional insurance. This is quite alarming as almost half of the respondent did not appreciate the distinctive nature of takaful concept.

On the second question pertaining to the position of the takaful customers compared to conventional insurance, $38 \%$ agreed or strongly agreed that there is no difference between takaful and conventional insurance customers.

However, the result for question 3 shows that more than $50 \%$ of the respondent willing to spend more time for voluntary training on takaful products to improve their knowledge before they could market it.

The above shows that there is still lacking of understanding on the true nature of takaful and its distinctive feature compared to insurance, although they had spent more time for training for takaful. However, majority of the respondents or $86 \%$ agreed that takaful is based on charity and helping each other. This shows that basically they understood the underlying concept of takaful which is based on charity and helping each other.

The second part of the survey focuses on the religious and ethical aspects as marketing points. 5 questions were asked in this part. The result for first question shows that $62 \%$ of the respondents like to explain to the potential customers the distinctive feature of takaful compared to conventional insurance.

The second question from this part interestingly shows that majority of the respondents or $81 \%$ agreed that the religious concept of takaful is a good marketing or selling point. On the question on the importance of religious and ethical aspect, $46 \%$ view that religious and ethical aspects are more important to the customers compared to investment benefits.

\footnotetext{
1 Islamic Financial Services Act 2012, Schedule 8, Section 3(2)

2 Islamic Financial Services Act 2012, Schedule 8, Section 3(3)

3 Islamic Financial Services Act 2012, Schedule 8, Section 6
} 
To measure the initiative taken to explain the religious aspect of takaful benefit like badal hajj or charity, $57 \%$ responded that they will explain even though not requested by the customer. It follows that the majority has taken the initiative to explain. It is also interesting to note that $71 \%$ of the agents agreed that they always explain to the customer that family takaful will religiously benefit the person covered even after their death.

The result of the above survey shows that majority of the takaful agents understood the underlying concept of takaful and its religious and ethical aspect, although improvements should be made to enhance their understanding. This shows that they are capable to explain to the potential customers and consequently leveraging on these aspects in their marketing strategy. The result also shows that they had actually leveraged on the ethical and religious aspect in their marketing by taking the initiative to explain to potential customer.

\section{Conclusion}

The very spirit and philosophy of takaful is closely related to Islamic teachings of helping each other in the times of need. While the main objective of takaful from the perspective of the participant is to serve as an alternative for the Muslims to fulfill their insurance needs in a Shariah compliant manner, it also provide other religious benefits. Thus participating in a takaful scheme, while aimed mainly at gaining protection against the risks, could also be perceived as a noble act of helping fellow participants as well as other religious benefits like settling debt, fulfillment of zakat and hajj duties as well as other charitable acts which is important for the Muslim for their life after death. Takaful also imbued and augmented with some ethical aspects whereby principles of utmost good faith, takaful underwriting procedure and insurable interest had been firmly established in takaful.

The analysis of the survey conducted shows that most of the takaful agents understood the distinctive nature of takaful and actually to some extent leveraged on the ethical and religious aspects in marketing takaful. As the studies (Ahmad Nordin, 2007) had shown that takaful market penetration is still very low even among the Muslims, it is a challenge to takaful agents to convince their potential participants by associating religious and ethical aspects with the worldly act of participating in takaful.

\section{References}

[1] Ahmad Nordin, Mohd Tarmidzi. (2007). Strengths and Opportunities of Takaful: the Spiritual Dimension. In J. Sohail (Ed.) Islamic Insurance: Trends, Opportunities and the Future of Takaful. United Kingdom: Euromoney Books.

[2] Ahmad, Syed Waseem (1991). Islamic Insurance in Malaysia. In Mohammad Ariff (Ed.) The Muslim Private Sector in Southeast Asia. Singapore: Institute of Southeast Asian Studies.

[3] Bakar, Daud (2009). Shariah Principles Governing Takaful Models, In Archer, Simon (Ed.) Takaful Islamic Insurance. Singapore: John Wiley \& Sons (Asia) Pte Ltd.

[4] Billah, Mohd Ma'sum. (2003). Islamic and Modern Insurance: Principles and Practices. Kuala Lumpur: Ilmiah Publishers.

[5] BIRT. (1996) Takaful (Islamic Insurance) Concept and Operational System from Practitioners Perspective. Kuala Lumpur: BIMB Institute of Research and Training.

[6] Hugh, Cockrell. (1987). Witherby's Dictionary of Insurance (2 ${ }^{\text {nd }}$. ed.). London: Witherby \& Co. Ltd.

[7] Islamic Financial Services Act (IFSA) 2012

[8] INCEIF, (2012) Takaful Realities and Challenges: Kuala Lumpur: Pearson Malaysia Sdn Bhd.

[9] ISRA. (2011) Islamic Financial System: Principles and Operations. Kuala Lumpur: International Shariah research Academy (ISRA).

[10] Mahmood, Nik Ramlah. (1991). Takaful: The Islamic System of Mutual Insurance - The Malaysian Experience. Arab Law Quarterly, Vol 6. London: Graham and Trotman.

[11] Rubin, Harvey W. (2000). Dictionary of Insurance Terms, $4^{\text {th }}$ ed., New York: Barron Educational Series.

[12] Takaful Act 1984 